\title{
EFFECT OF PHOSPHORUS, ZINC AND SULPHUR APPLICATION ON THE GROWTH CHARACTERS, P AND ZN UPTAKE, YIELD COMPONENTS OF WHEAT PLANT GROWN ON CALCAREOUS SOIL \\ Sharaf, A. I. \\ Dept. of Soil and Water Sciences, Fac. of Agric., El-Shatby, Alex. Univ. Alex., Egypt.
}

\begin{abstract}
A field experiment was conducted over two successive seasons (2006/2007 and 2007/2008) at Borg El-Arab area, on North western of Egypt and about $65 \mathrm{~km}$ from Alexandria city, to study the effect of phosphorus, sulphur and zinc applications on $P$ and $\mathrm{Zn}$ uptake, growth, yield and its components of wheat plant (Triticum aestivum L.) CV. Sakha 69. Phosphorus rates were 0,60 and $120 \mathrm{~kg} \mathrm{P}_{2} \mathrm{O}_{5} \mathrm{ha}^{-1}$, as superphosphate, and zinc application rates were 0,5 and $10 \mathrm{~kg} \mathrm{ZnO} \mathrm{ha}^{-1}$ as $\left(\mathrm{ZnSO}_{4} .7 \mathrm{H}_{2} \mathrm{O}\right)$ either without or with one sulphur application rate $\left(100 \mathrm{~kg} \mathrm{~S} \mathrm{ha}^{-1}\right)$. The used soil type was Aridisols (Calciorthids); calcareous sandy clay loam soil. The results obtained showed that plant height and dry weight/plot were responded to $P$ and $\mathrm{Zn}$ treatments and this response was significantly increased in the presence of sulphur application. The $P$ uptake by roots was significantly increased with increasing $P$ rates, when combined with added $Z n$ without of $S$ application, at the booting (ZGS 31 ) and soft dough stages (ZGS 45). On the other hand, in the presence of $S$, there were insignificant increase of $P$ uptake by roots and significant increase of $P$ uptake by shoots with increasing of $P$ rates when combined with increasing of $\mathrm{Zn}$ rates as compared with the control. The $\mathrm{Zn}$ uptake was significantly increased in roots and significantly decreased in the shoots with increasing of $P$ and $Z n$ rates without $S$ application as compared to the control. Whereas, plots that treated with $S$ gave the highest shoot $\mathrm{Zn}$ uptake. Increasing $\mathrm{P}$ and $\mathrm{Zn}$ rates significantly increased grains $\mathrm{P}$ and $\mathrm{Zn}$ uptake and the highest uptake values were obtained in plots that treated with $\mathrm{P}, \mathrm{Zn}$ and $\mathrm{S}$. The application of $\mathrm{P}$ and $\mathrm{Zn}$ without $\mathrm{S}$ did not significantly increase the yield and its components as compared with the control. The highest values of yield and its components were obtained at the highest rates of $\mathrm{P}$ and $\mathrm{Zn}$ that combined with $100 \mathrm{~kg} \mathrm{~S} \mathrm{ha}^{-1}$, and those values were 548, 794, 3.38, 4.72, 15.88, 20.60, 22.91 and 13.28 for number of spikes $/ \mathrm{m}^{2}$, weight of spikes $\left(\mathrm{g} / \mathrm{m}^{2}\right)$, grain index $(\mathrm{g})$, grain yield (ton $\mathrm{ha}^{-1}$ ), straw yield (ton ha-1), biological yield (ton ha $\left.{ }^{-1}\right)$, harvest index (\%) and protein percentage, respectively.
\end{abstract}

\section{INTRODUCTION}

Wheat occupies about 33\% of the total winter crop area in Egypt and is the major staple crop, consumed mainly as bread (Kherallah et al., 2000). More than one-third of the daily caloric intake of Egyptian consumers and $45 \%$ of their total daily protein consumption is derived from wheat (Kherallah et al., 2000).

Zinc deficiency has been reported to be the most widespread micronutritional disorder of the food crops in many areas of the world (Kanwar and Youngdahl, 1985). Global studies initiated by FAO and some projects recorded $\mathrm{Zn}$ deficiency in $50 \%$ of the soil samples collected from 25 countries (FAO, 2002; IFPRI, 2002 and IFPRI, 2004). Zinc deficiency is common on 
Sharaf, A. I.

neutral and calcareous soils with high $\mathrm{pH}$, as well as intensively cropped soils, soils with high available phosphorus and sandy soils (Rammah, 1989; IFAD, 1991 and FAO, 2002).

Wheat response to zinc applications on calcareous soils showed varying magnitude of intensity from many wheat growing countries (Sillanpaa, 1982 and Sillanpaa, 1990). In other wheat producing regions, zinc applications have proved as beneficial for wheat production on $\mathrm{Zn}$-deficient soils. Zinc deficiency is common on calcareous soils with high available phosphorus and silicon. (Singh et al., 2005).

Heavy applications of phosphorous fertilizers to soils, low in available zinc, can also induce zinc deficiency (Mengel and Kirkby, 2001). Mechanisms of $P$ induced $Z n$ deficiency was suggested by Parker et al., (1992) who reported that decreased solubility of soil $\mathrm{Zn}$ may result from enhanced sorption of $\mathrm{Zn}$ by hydrous oxides, and to the dilution effect due to the increase in dry matter production. Bergman (1992) found that high P levels inhibit translocation of $\mathrm{Zn}^{+2}$ to shoot, and $\mathrm{Zn}$ levels in the leaves are mostly effected, while $Z^{+2}$ uptake by the root were less affected.

Zhu et al., (2001) demonstrated that an increase in available $P$ in soil was associated with lower $\mathrm{Zn}$ concentrations in shoots and there was inverse relationship between shoot $\mathrm{P}$ and $\mathrm{Zn}$ concentrations. Correction of $\mathrm{Zn}$ deficiency via fertilization is not always successful due to agronomic and economic factors. Some of these factors include reduced availability of $\mathrm{Zn}$ due to topsoil drying, subsoil constraints, disease interactions, and cost of fertilizer in developing countries (Graham and Rengel, 1993).

When calcareous soil wheat producers, at Borg El-Arab region, reviewed soil test reports, they often find that DTPA-extractable zinc levels are below $0.3 \mathrm{ppm}$. Consultants and researchers agree these levels seem "pretty low", but questions about the effect of $\mathrm{Zn}$ fertilization on plant tissue concentrations and uptake of $\mathrm{Zn}$ with $\mathrm{P}$ fertilizer application to calcareous soil need to be answered.

In recent years, S-deficiency has become an increasing problem for agriculture resulting in decreased crop quality parameters and yield (Hawkesford, 2000). Attention has been paid for application of elemental sulphur to soils to correct soil alkalinity. Elemental sulphur is oxidized by soil microorganisms to sulphuric acid, which in turn lowers soil pH, improve soil structure and increases the availability of certain macro- and micronutrients (El-Shahawy, 2004).

The objective of this study, therefore, was to evaluate the interaction effects of $P$ and $Z n$, with and without $S$ application on the growth characters, $\mathrm{P}$ and $\mathrm{Zn}$ uptake, and yield components of wheat plant grown on $\mathrm{Zn}$ deficiency calcareous soil for two successive seasons

\section{MATERIALS AND METHODS}

Sit of field experimental:

A field experiment was conducted during two successive winter seasons (2006/2007 and 2007/2008) at Borg El-Arab area (North western coastal zone of Egypt) about $65 \mathrm{~km}$ west Alexandria city. The soil type of this area is Aridisols (Calciorthids) with sandy clay loam texture. 


\section{Soil characteristics:}

Composite surface soil samples $(0-30 \mathrm{~cm})$ were collected from experimental area prior to sowing, air-dried and ground to pass a 2-mm sieve. The mean values of the main soil chemical and physical characteristics are presented in Table (1).

Particle size distribution of soil (sand, silt and clay) was determined by the pipette method (Gee and Bauder, 1986). The amount of total carbonate was measured by Calcimeter method (FAO, 1970). The soil pH and electrical conductivity (E.C) were determined in 1:2.5 soil: water suspension and saturated soil paste extract, respectively, as described by Richards (1954). The soil CEC was determined by saturating the soil with $1 \mathrm{M} \mathrm{NaOAc}$ at $\mathrm{pH}$ 8.2 according FAO (1970). The amount of available $P$ was extracted by Olsen method with $0.5 \mathrm{M} \mathrm{NaHCO}_{3}$ at $\mathrm{pH} 8.5$ and $\mathrm{P}$ was colorimetrically measured by ascorbic acid/ammonium molybdate method according Page et al. (1982). The amount of available $\mathrm{K}$ was extracted by $1.0 \mathrm{M} \mathrm{NH}_{4} \mathrm{OAc} \mathrm{K}$ was measured by flame photometer (FAO, 1970). The amounts of $\mathrm{NO}_{3}-\mathrm{N}$ and organic matter (OM) were determined according Page et al., (1982). Soil testing of $S$ was extracted by $\mathrm{Ca}\left(\mathrm{H}_{2} \mathrm{PO}_{4}\right)_{2}$ and $\mathrm{CaCl}_{2}$ for the determination of free + adsorbed $\mathrm{SO}_{4}{ }^{-2}$ and free $\mathrm{SO}_{4}{ }^{-2}$, respectively (Tabatabai, 1982 ) and the extracted $\mathrm{SO}_{4}{ }^{-2}$ was colorimetrically measured as described by Hesse (1972). Soil testing of $\mathrm{Zn}$ was determined by DTPA extraction (Lindsay and Norvell, 1978). The amounts of total N, P and $\mathrm{Zn}$ in plant tissues were determined according to Chapman and Pratt (1961). The Zn concentration was measured by Perkin Elmer atomic absorption spectrophotometer Model 2380.

Table (1): The mean values of the main chemical and physical properties of the experimental field soil before sowing.

\begin{tabular}{|c|c|c|c|}
\hline Soil variable & Mean & Soil variable & Mean \\
\hline $\mathrm{EC}, \mathrm{dS} \mathrm{m}^{-1}$ (sat. soil paste ext.) & 3.6 & $\mathrm{NO}_{3}-\mathrm{N}$ & $30.0 \mathrm{ppm}$ \\
\hline $\mathrm{pH}(1: 2.5$, soil : water $)$ & 8.40 & $\left\{\mathrm{Ca}\left(\mathrm{H}_{2} \mathrm{PO}_{4}\right)_{2}+\mathrm{CaCl}_{2}\right\}-\mathrm{S}$ & $22.0 \mathrm{ppm}$ \\
\hline O.M, (\%) & 0.55 & Particle size distribution: & \\
\hline Total Carbonate (\%) & 19.3 & Sand & 21 \\
\hline $\mathrm{NaHCO}_{3}-\mathrm{P}$ ( $\mu \mathrm{g} \mathrm{P} / \mathrm{g}$ soil) & 6.5 & Silt & 63 \\
\hline $\mathrm{NaHCO}_{3}-\mathrm{K}$ ( $\mu \mathrm{g} \mathrm{K} / \mathrm{g}$ soil $)$ & 160.0 & Clay & 16 \\
\hline C.E.C (me/100 g soil) & 112.0 & Texture & $S C L$ * \\
\hline DTPA-Zn ( $\mu \mathrm{g} Z \mathrm{Zn} / \mathrm{g}$ soil) & 0.30 & & \\
\hline
\end{tabular}

\section{Field Experimental Design and Treatments:}

The field experiment was carried out in a split-plot design with four replicates. The main plots were subjected to phosphorus treatments $(0,60$ and $\left.120 \mathrm{~kg} \mathrm{P}_{2} \mathrm{O}_{5} \mathrm{ha}^{-1}\right)$ and the sub-plots were subjected to zinc treatments $(0$, 5 and $10 \mathrm{~kg} \mathrm{ZnO} \mathrm{ha}^{-1}$ ) either without $S$ application or with $100 \mathrm{~kg} \mathrm{~S} \mathrm{ha}^{-1}$ as elemental sulphur. The area of each sub plot was $10.5 \mathrm{~m}^{2}(3.0 \mathrm{~m}$ wide and $3.5 \mathrm{~m}$ in length). The sowing was done using drill hand machine on 25 September in the first season and 28 September in the second season. The harvested area of sub plot was $8.4 \mathrm{~m}^{2}$ (2.4 $\mathrm{m}$ in width and $3.5 \mathrm{~m}$ in length) to determine yield of grains and straw. 
The $\mathrm{P}$ treatments were applied at the rates of 0,60 and $120 \mathrm{~kg} \mathrm{P}_{2} \mathrm{O}_{5} \mathrm{ha}^{-1}$ as superphosphate $\left(15.5 \% \mathrm{P}_{2} \mathrm{O}_{5}\right)$ and $\mathrm{Zn}$ treatments were applied at the rates of 0,5 and $10 \mathrm{~kg} \mathrm{ZnO} \mathrm{ha}^{-1}$ as fine granular $\mathrm{ZnSO}_{4} .7 \mathrm{H}_{2} \mathrm{O}(28.2 \% \mathrm{ZnO})$. While sulphur was applied at rate of $100 \mathrm{~kg} \mathrm{~S} \mathrm{ha}^{-1}$ as elemental sulphur, which was added to sub plots that treated with Sulphur.

The distributions of treatments were:

1. Control: without adding any treatments.

2. $60 \mathrm{~kg} \mathrm{P}_{2} \mathrm{O}_{5} \mathrm{ha}^{-1}, 5 \mathrm{~kg} \mathrm{ZnO}^{-1}$ and $0 \mathrm{~kg} \mathrm{~S} \mathrm{ha}^{-1},\left(\mathrm{P}_{60}-\mathrm{Zn}_{5}-\mathrm{S}_{0}\right)$.

3. $60 \mathrm{~kg} \mathrm{P}_{2} \mathrm{O}_{5} \mathrm{ha}^{-1}, 10 \mathrm{~kg} \mathrm{ZnO} \mathrm{ha}^{-1}$ and $0 \mathrm{~kg} \mathrm{~S} \mathrm{ha}^{-1},\left(\mathrm{P}_{60}-\mathrm{Zn}_{10}-\mathrm{S}_{0}\right)$.

4. $60 \mathrm{~kg} \mathrm{P}_{2} \mathrm{O}_{5} \mathrm{ha}^{-1}, 5 \mathrm{~kg} \mathrm{ZnO} \mathrm{ha}^{-1}$ and $100 \mathrm{~kg} \mathrm{~S} \mathrm{ha}^{-1},\left(\mathrm{P}_{60}-\mathrm{Zn}_{5}-\mathrm{S}_{100}\right)$.

5. $60 \mathrm{~kg} \mathrm{P}_{2} \mathrm{O}_{5} \mathrm{ha}^{-1}, 10 \mathrm{~kg} \mathrm{ZnO} \mathrm{ha}^{-1}$ and $100 \mathrm{~kg} \mathrm{~S} \mathrm{ha}^{-1},\left(\mathrm{P}_{60}-\mathrm{Zn}_{10}-\mathrm{S}_{100}\right)$.

6. $120 \mathrm{~kg} \mathrm{P}_{2} \mathrm{O}_{5} \mathrm{ha}^{-1}, 5 \mathrm{~kg} \mathrm{ZnO} \mathrm{ha}^{-1}$ and $0 \mathrm{~kg} \mathrm{~S} \mathrm{ha}^{-1},\left(\mathrm{P}_{120}-\mathrm{Zn}_{5}-\mathrm{S}_{0}\right)$.

7. $120 \mathrm{~kg} \mathrm{P}_{2} \mathrm{O}_{5} \mathrm{ha}^{-1}, 10 \mathrm{~kg} \mathrm{ZnO} \mathrm{ha}^{-1}$ and $0 \mathrm{~kg} \mathrm{~S} \mathrm{ha}^{-1},\left(\mathrm{P}_{120}-\mathrm{Zn}_{10}-\mathrm{S}_{0}\right)$.

8. $120 \mathrm{~kg} \mathrm{P}_{2} \mathrm{O}_{5} \mathrm{ha}^{-1}, 5 \mathrm{~kg} \mathrm{ZnO} \mathrm{ha}^{-1}$ and $100 \mathrm{~kg} \mathrm{~S} \mathrm{ha}^{-1},\left(\mathrm{P}_{120}-\mathrm{Zn}_{5}-\mathrm{S}_{100}\right)$.

9. $120 \mathrm{~kg} \mathrm{P}_{2} \mathrm{O}_{5} \mathrm{ha}^{-1}, 10 \mathrm{~kg} \mathrm{ZnO} \mathrm{ha}{ }^{-1}$ and $100 \mathrm{~kg} \mathrm{~S} \mathrm{ha}^{-1},\left(\mathrm{P}_{120}-\mathrm{Zn}_{10}-\mathrm{S}_{100}\right)$.

\section{Cultural Practices}

The experimental area was ploughed, rolled and divided into plots and then the $P$ and $Z n$ fertilizers were added to surface layer $(0-15 \mathrm{~cm})$ of experimental units while sulfur was applied as broadcast, a week before sowing. Wheat (Triticum aestivum L.) Sakha 69 variety was planted at a rate of $120 \mathrm{~kg}$ per hectare. The seed germination test was $90 \%$.

The agricultural practices and irrigation schedule of the wheat plant were done according to the recommendations of the Ministry of Agriculture and Land Reclamation (MALR). However, to provide for maximum yield, irrigation management levels were maintained to soil moisture does not drop below 65 per cent of the water holding capacity of soil of the root zone during the growing seasons.

\section{Sampling:}

Plant samples were collected from the center of each plot. Three plant samples were taken at three stages of plant growth according to Zadoks Growth Stage ZGS (Zadoks et.al., 1974) and Feekes Scale (Miller, 1992) as follows:

1- Vegetative growth stage and the secondary root system were developing, at 33 days after sowing (33 DAS), after most tillering had been formed (5 tillers); elongation of stem and the first node was detectable in stem (ZGS 31, Feekes 6).

2- The booting stage, at 55 days after sowing (55 DAS). The head was fully developed, but had not yet emerged from the leaf sheath below the flag leaf and before beginning flowering stage (ZGS 45, Feekes 10).

3- The soft dough stage; kernels of spiked panicle were developing after pollination, the kernel begins filling and accumulating starch and protein rapidly and its dry weight was increased. This stage was at 75 days after sowing (75 DAS) (ZGS 85, Feekes 11.2).

At harvest, the plant samples were taken on March 2007 and 2008 for both successive seasons. The plant samples (from one square meter) were taken randomly from the middle area of each plot (three replicates) to determine plant height "cm", dry weight "g/plot", number of spikes $/ \mathrm{m}^{2}$, weight of spikes " $\mathrm{g} / \mathrm{m}^{2 "}$, grain index "g" (100 grain weight). In addition, grain yield 
"ton ha-1", straw yield "ton ha-1", biological yield "ton ha-1" were determined for the whole area of experimental units. The other three replicates were taken for the determination of the yield and then converted to yield per hectare and harvest index (grain yield/ biological yield $\times 100$ ).

The samples of plant materials were subjected to washing by tap water then by distilled water and dried gently by spreading on soft paper sheets to remove excess water, placed in paper bags, and dried in a forced-air oven at $70^{\circ} \mathrm{C}$ for $48 \mathrm{hrs}$ before recording the data of the growth characters and plant tissue analysis of elements. The oven-dried plant materials were ground in a Wiley mill to pass through a 1-mm sieve and analysis for N, P and $\mathrm{Zn}$ according to Chapman and Pratt (1961).

Crude protein content of grains was calculated by multiplying $\mathrm{N}$ percent by the conversion factor 6.25 (El-Moatasem et al., 1993). The statistical analysis of the obtained data was carried out according to the method described by Gomez and Gomes (1984).

\section{RESULTS AND DISCUSSION}

Table (1) showed that the experimental soil of Borg El-Arab area had relatively low of total soluble salts $\left(E . C_{e}=3.6 \mathrm{dSm}^{-1}\right)$, and very low of both O.M (0.55\%), low available $\mathrm{P}\left(6.5 \mu \mathrm{g} \mathrm{P} \mathrm{g}{ }^{-1}\right.$ soil), available $\mathrm{K}\left(160 \mu \mathrm{g} \mathrm{K} \mathrm{g}^{-1}\right.$ soil), low sulfate ion, and very low available $\mathrm{Zn}\left(0.3 \mu \mathrm{gn} \mathrm{g}^{-1}\right.$ soil). It is clear that the soil is $\mathrm{Zn}$-deficient and generally infertile for wheat production.

\section{Some plant growth characters:}

Tables 2 and 3 showed the response of plant length and dry weight/plant of wheat plant, at the different growth stages for an average of two seasons (2006/2007 and 2007/2008). Data recorded in Table (2) show that, irrespective of $\mathrm{Zn}$ rates, $\mathrm{P}$ fertilizer significantly increased plant height and dry weight/plant as compared with the control at the different growth stages. This may be attributed to the role of $P$ in plant metabolism processes, root growth and proliferation of plants that increase nutrient uptake. It is obvious that the increase of nutrients absorption by plant lead to an increase in its dry weights (Mengel and Kirkby. 2001). The results also showed that $P$ and $Z n$ treatments significantly increased the growth characters in the presence of sulphur at all growth stages. Also the effect of $P$ was more pronounced when $\mathrm{Zn}$ was added in the presence of $S$. This positive effect of sulphur may be due to its oxidation by soil microorganisms to sulphuric acid that decreases soil $\mathrm{pH}$, improves soil structure and increases the availability of certain nutrient elements. Abd El-Fattah et al.(1996) mentioned similar explanation. The highest values of plant height and dry weight/plot were obtained with the treatment: $120 \mathrm{~kg} \mathrm{P}_{2} \mathrm{O}_{5} \mathrm{ha}^{-1}$ and $10 \mathrm{~kg} \mathrm{ZnO} \mathrm{ha}^{-1}$ plus of $100 \mathrm{~kg} \mathrm{~S} \mathrm{ha}^{-1}$, which recorded of $91 \mathrm{~cm}$ and $40.8 \mathrm{~g} /$ plant, and $119 \mathrm{~cm}$ and $125.8 \mathrm{~g} /$ plant, respectively at soft dough stage (ZGS 85 ) and harvest (Table, 3 ). 
Sharaf, A. I.

Table (2): The mean values of plant height and dry weight of the three growth stages (ZGS 31, ZGS 45 and ZGS 85 ) of wheat plant grown in the two seasons $\left(1^{\text {st }}\right.$ and $\left.2^{\text {nd }}\right)$ as affected by phosphorus, sulphur and zinc treatments.

\begin{tabular}{|c|c|c|c|c|c|c|c|c|c|c|c|c|c|c|c|c|c|c|}
\hline \multirow{2}{*}{\multicolumn{3}{|c|}{ Treatments * }} & \multicolumn{6}{|c|}{ Plant height (cm) } & \multicolumn{6}{|c|}{ Dry weight $\left(\mathbf{g} / \mathbf{m}^{2}\right)$} & \multicolumn{4}{|c|}{ Harvest stage } \\
\hline & & & \multicolumn{2}{|c|}{ ZGS 31} & \multicolumn{2}{|c|}{ ZGS 45} & \multicolumn{2}{|c|}{ ZGS 85} & \multicolumn{2}{|c|}{ ZGS 31} & \multicolumn{2}{|c|}{ ZGS 45} & \multicolumn{2}{|c|}{ ZGS 85} & \multicolumn{2}{|c|}{$\begin{array}{c}\text { Plant } \\
\text { height } \\
\text { (cm) }\end{array}$} & \multicolumn{2}{|c|}{$\begin{array}{l}\text { Dry weight } \\
\text { (g/plant) }\end{array}$} \\
\hline $\mathbf{P}$ & $\mathbf{S}$ & $\mathbf{Z n}$ & $1^{\text {st }}$ & $2^{\text {nd }}$ & $1^{\text {st }}$ & $2^{\text {nd }}$ & $1^{\text {st }}$ & & $1^{\text {st }}$ & $2^{\text {nd }}$ & $1^{\text {st }}$ & $2^{\text {nd }}$ & $1^{\text {st }}$ & $2^{\text {nd }}$ & $1^{\text {st }}$ & $2^{\text {nd }}$ & $1^{\text {st }}$ & $2^{\text {nd }}$ \\
\hline \multirow{6}{*}{0} & \multirow{3}{*}{0} & 0 & 17 & 19 & 33 & 37 & 50 & 46 & 5.2 & 5.0 & 6.2 & 6.4 & 20.6 & 23.0 & 60 & 64 & 53.3 & 51.1 \\
\hline & & 5 & 18 & 21 & 40 & 38 & 53 & 55 & 5.1 & 5.3 & 7.3 & 7.7 & 22.0 & 22.8 & 63 & 69 & 50.5 & 51.1 \\
\hline & & 10 & 20 & 22 & 36 & 38 & 55 & 57 & 5.1 & 5.3 & 7.5 & 7.7 & 22.8 & 23.2 & 68 & 72 & 51.0 & 53.0 \\
\hline & \multirow{3}{*}{100} & 0 & 22 & 24 & 37 & 39 & 56 & 58 & 5.2 & 5.4 & 6.4 & 6.8 & 22.8 & 23.4 & 69 & 73 & 52.8 & 53.6 \\
\hline & & 5 & 24 & 26 & 40 & 42 & 54 & 58 & 5.0 & 5.4 & 7.5 & 7.9 & 22.0 & 22.4 & 69 & 71 & 53.1 & 54.5 \\
\hline & & 10 & 26 & 28 & 41 & 43 & 53 & 55 & 5.3 & 5.6 & 7.4 & 7.8 & 22.9 & 23.5 & 66 & 70 & 53.7 & 54.7 \\
\hline \multirow{6}{*}{60} & \multirow{3}{*}{0} & 0 & 22 & 24 & 42 & 46 & 62 & 64 & 5.4 & 5.6 & 8.0 & 8.4 & 27.0 & 27.4 & 79 & 83 & 60.0 & 64.0 \\
\hline & & 5 & 23 & 25 & 43 & 47 & 64 & 66 & 5.7 & 5.9 & 8.3 & 8.5 & 25.1 & 25.9 & 73 & 77 & 63.0 & 66.0 \\
\hline & & 10 & 27 & 29 & \begin{tabular}{|l|}
46 \\
\end{tabular} & 48 & 65 & 67 & 5.3 & \begin{tabular}{|l|}
3.5 \\
\end{tabular} & 8.7 & 8.9 & 25.0 & 25.6 & \begin{tabular}{|l|}
70 \\
\end{tabular} & 74 & 66.1 & 67.7 \\
\hline & \multirow{3}{*}{100} & 0 & 30 & 34 & \begin{tabular}{|l|}
47 \\
\end{tabular} & 51 & \begin{tabular}{|l|}
75 \\
\end{tabular} & 79 & \begin{tabular}{|l|}
6.1 \\
\end{tabular} & 6.5 & 8.0 & 8.4 & 29.1 & 29.7 & \begin{tabular}{|l|}
78 \\
\end{tabular} & 82 & 66.0 & 67.0 \\
\hline & & 5 & 34 & 36 & 50 & 54 & 80 & 82 & 6.4 & 6.8 & 8.6 & 9.0 & 29.0 & 29.8 & 89 & 93 & 75.0 & 75.8 \\
\hline & & 10 & 40 & 42 & 56 & 60 & 81 & 83 & 6.6 & 6.7 & 9.3 & 9.7 & 33.5 & 34.1 & \begin{tabular}{|l|}
97 \\
\end{tabular} & 101 & 83.9 & 84.9 \\
\hline \multirow{6}{*}{120} & \multirow{3}{*}{0} & 0 & 28 & 30 & 49 & 51 & 67 & 71 & 6.3 & 6.5 & 8.2 & 8.4 & 26.4 & 27.0 & \begin{tabular}{|l|}
74 \\
\end{tabular} & 78 & 68.0 & 68.8 \\
\hline & & 5 & 21 & 25 & 48 & 50 & \begin{tabular}{|l|}
74 \\
\end{tabular} & 76 & 5.9 & 6.1 & 8.1 & 8.3 & 25.9 & 26.1 & 75 & 82 & 71.5 & 72.5 \\
\hline & & 10 & 20 & 22 & 45 & 47 & 75 & 81 & 5.7 & 5.9 & 8.3 & 8.5 & 21.8 & 22.2 & \begin{tabular}{|l|}
81 \\
\end{tabular} & 87 & 72.7 & 73.7 \\
\hline & \multirow{3}{*}{100} & 0 & 33 & 37 & 52 & 56 & \begin{tabular}{|l|}
77 \\
\end{tabular} & 79 & 5.9 & 6.1 & 9.8 & 10.3 & 31.5 & 32.5 & 90 & 96 & 87.9 & 89.3 \\
\hline & & 5 & 38 & 42 & 57 & 59 & 83 & 87 & 6.6 & 7.0 & 13.5 & 14.1 & 38.5 & 39.1 & \begin{tabular}{|l|l}
108 \\
\end{tabular} & 114 & 97.7 & 99.1 \\
\hline & & 10 & 45 & 47 & \begin{tabular}{|l|}
62 \\
\end{tabular} & 66 & \begin{tabular}{|l|}
90 \\
\end{tabular} & \begin{tabular}{|l|}
92 \\
\end{tabular} & \begin{tabular}{|l|}
9.0 \\
\end{tabular} & 9.4 & 18.2 & 19.0 & 40.3 & 41.3 & 115 & 123 & 124.8 & 126.8 \\
\hline
\end{tabular}

Table (3): The average values of plant height and dry weight of wheat plant at the three different growth stages for the two grown seasons as affected by phosphorus, sulphur and zinc treatments.

\begin{tabular}{|c|c|c|c|c|c|c|c|c|c|c|}
\hline \multirow{2}{*}{\multicolumn{3}{|c|}{ Treatments * }} & \multicolumn{6}{|c|}{ Growth stage } & \multicolumn{2}{|c|}{ Harvest stage } \\
\hline & & & \multicolumn{3}{|c|}{ Plant height $(\mathrm{cm})$} & \multicolumn{3}{|c|}{ Dry weight $\left(\mathbf{g} / \mathbf{~ m}^{2}\right)$} & \multirow{2}{*}{$\begin{array}{c}\text { Plant } \\
\text { height } \\
\text { (cm) }\end{array}$} & \multirow{2}{*}{$\begin{array}{c}\text { Dry } \\
\text { weight } \\
\text { (g/plant) }\end{array}$} \\
\hline $\mathbf{P}$ & $\mathbf{s}$ & Zn & ZGS 31 & ZGS 45 & ZGS 85 & ZGS 31 & ZGS 45 & ZGS 85 & & \\
\hline \multirow{6}{*}{0} & \multirow{3}{*}{0} & 0 & 18 & 35 & 48 & 5.1 & 6.3 & 21.8 & 62 & 52.2 \\
\hline & & 5 & 20 & 39 & 54 & 5.2 & 7.5 & 22.4 & 66 & 50.8 \\
\hline & & 10 & 21 & 37 & 56 & 5.2 & 7.6 & 23.0 & 70 & 52.0 \\
\hline & \multirow{3}{*}{100} & 0 & 23 & 38 & 57 & 5.3 & 6.6 & 23.1 & 71 & 53.2 \\
\hline & & 5 & 25 & 41 & 56 & 5.2 & 7.7 & 22.2 & 70 & 53.8 \\
\hline & & 10 & 27 & 42 & 54 & 5.4 & 7.6 & 23.2 & 68 & 54.2 \\
\hline \multirow{6}{*}{60} & \multirow{3}{*}{0} & 0 & 23 & 44 & 63 & 5.6 & 8.2 & 27.2 & 81 & 62.0 \\
\hline & & 5 & 24 & 45 & 65 & 5.8 & 8.4 & 25.5 & 75 & 64.5 \\
\hline & & 10 & 28 & 47 & 66 & 5.4 & 8.8 & 25.3 & 72 & 66.9 \\
\hline & \multirow{3}{*}{100} & 0 & 32 & 49 & 77 & 6.3 & 8.2 & 29.4 & 80 & 66.5 \\
\hline & & 5 & 35 & 52 & 81 & 6.6 & 8.8 & 29.4 & 91 & 75.4 \\
\hline & & 10 & 41 & 58 & 82 & 6.7 & 9.5 & 33.8 & 99 & 84.4 \\
\hline \multirow{6}{*}{120} & \multirow{3}{*}{0} & 0 & 29 & 50 & 69 & 6.4 & 8.3 & 26.7 & 76 & 68.4 \\
\hline & & 5 & 23 & 49 & 75 & 6.0 & 8.2 & 26.0 & 79 & 72.0 \\
\hline & & 10 & 21 & 46 & 79 & 5.8 & 8.4 & 22.0 & 84 & 73.2 \\
\hline & \multirow{3}{*}{100} & 0 & 35 & 54 & 78 & 6.0 & 10.1 & 32.0 & 93 & 88.6 \\
\hline & & 5 & 40 & 58 & 85 & 6.8 & 13.8 & 38.8 & 111 & 98.4 \\
\hline & & 10 & 46 & 64 & 91 & 9.2 & 18.6 & 40.8 & 119 & 125.8 \\
\hline \multicolumn{3}{|c|}{$S D(0.05)$} & 7.28 & 8.92 & 20.8 & 0.64 & 1.88 & 3.36 & 7.80 & 4.85 \\
\hline
\end{tabular}

${ }^{*}$ Treatments= P: $\mathrm{kg} \mathrm{P}_{2} \mathrm{O}_{5} / \mathrm{ha}, \mathrm{S}: \mathrm{kg} \mathrm{S} / \mathrm{ha}$ and $\mathrm{Zn:} \mathrm{kg} \mathrm{ZnO/ha}$. 


\section{Phosphorus uptake:}

Table (4) show that $P$ uptake was increased in roots and shoots with increasing $P$ rates, as compared to the control at all growth stages. The $P$ uptake by roots was significantly increased with increasing $P$ rates combined with added $\mathrm{Zn}$ in the absence of S application, at the booting (ZGS 45) and soft dough (ZGS 85) stages. This result was not noticed at the first growth stage (ZGS 31). This may be due to the small size of roots. The results also showed that the $P$ uptake by roots in presence of $S$ was markedly but not significantly increased, where $P$ rates and combined with increased $\mathrm{Zn}$ rates at all growth stages.

Table (4): The average values of $P$ and $Z n$ uptake by roots and shoots of wheat plant at the three different growth stages (ZGS 31, ZGS 45 and ZGS 85) for the two grown seasons as affected by phosphorus, sulphur and zinc treatments.

\begin{tabular}{|c|c|c|c|c|c|c|c|c|c|c|c|c|c|c|c|c|}
\hline \multirow{2}{*}{\multicolumn{3}{|c|}{ Treatments * }} & \multicolumn{6}{|c|}{ P uptake, $\mathrm{mg} /$ plot } & \multicolumn{6}{|c|}{ Zn uptake, mg/plot } & \multicolumn{2}{|c|}{$\begin{array}{l}\text { Grain, at } \\
\text { harvest }\end{array}$} \\
\hline & & & \multicolumn{3}{|c|}{ Roots } & \multicolumn{3}{|c|}{ Shoots } & \multicolumn{3}{|c|}{ Roots } & \multicolumn{3}{|c|}{ Shoots } & \multirow{3}{*}{$\begin{array}{c}\mathrm{P} \\
\text { uptake, } \\
\text { mg/plot }\end{array}$} & \multirow{3}{*}{$\begin{array}{c}\text { Zn } \\
\text { uptake } \\
\text {, mg/ } \\
\text { plot }\end{array}$} \\
\hline D & $c$ & & 700 & 700 & 79 & & $7 \mathrm{CS}$ & 70 & ZGS & ZGS & & & ZGS & & & \\
\hline$r$ & & & 31 & 45 & 85 & 31 & 45 & 85 & 31 & & & & & & & \\
\hline \multirow{6}{*}{0} & \multirow{3}{*}{0} & \multirow{3}{*}{$\begin{array}{c}0 \\
5 \\
10\end{array}$} & 18 & & 43 & & 59 & 65 & 0.63 & 0.79 & $\overline{1.0}$ & 1.33 & 32 & & & 2.86 \\
\hline & & & 22 & & & 31 & & 58 & 0.66 & & & 1.3 & 79 & & & 3.22 \\
\hline & & & 29 & 4 & & 34 & & 70 & & & & & & & & 3.66 \\
\hline & \multirow{3}{*}{100} & 0 & 21 & 38 & 43 & 35 & 60 & 73 & 0.70 & 0.79 & 1. & 1.50 & .00 & & & 4.11 \\
\hline & & 5 & 23 & 40 & & 48 & 6 & 76 & 0.72 & & & 1.62 & 21 & & & 4.65 \\
\hline & & 10 & 29 & 43 & 55 & 53 & 68 & 80 & 0.68 & 0.83 & 1.71 & 1.74 & 2.28 & .91 & 232.6 & 5.15 \\
\hline \multirow{6}{*}{60} & \multirow{3}{*}{0} & 0 & 33 & 59 & $7 \varepsilon$ & 58 & 79 & 91 & 0.85 & 1.42 & 1.98 & 0.99 & 1.38 & & & 4.35 \\
\hline & & 5 & 35 & 66 & 82 & 34 & 60 & 76 & 1.15 & 1.7 & & 0.70 & & & 27 & 4.66 \\
\hline & & 10 & 38 & 68 & 9 & 32 & 48 & 62 & 1.47 & 1.99 & 3.10 & 0.41 & 0.84 & 75 & 6.6 & 5.02 \\
\hline & \multirow{3}{*}{100} & 0 & 30 & 46 & 58 & 59 & 89 & 97 & 0.89 & 0. & & 1.64 & 36 & & & 5.25 \\
\hline & & 5 & 33 & 50 & 60 & 62 & 99 & 105 & 0.62 & 0.76 & 1.60 & 1.94 & 2.28 & .31 & .4 & 5.90 \\
\hline & & 10 & 35 & 54 & & 82 & 103 & 111 & 0.45 & & & 2.25 & & & & 6.76 \\
\hline \multirow{6}{*}{120} & \multirow{3}{*}{0} & 0 & 35 & 70 & 85 & 68 & 89 & 99 & 0.89 & 1.26 & & 1.02 & 1.26 & 2.78 & 0.2 & 4.20 \\
\hline & & 5 & 41 & 74 & 8 & 44 & 63 & 84 & 1.22 & 1.58 & 2.59 & 0.72 & 1.16 & .32 & 272.2 & 4.88 \\
\hline & & 10 & 48 & 79 & 94 & 41 & 41 & 76 & 1.54 & 1.85 & 3. & 0.42 & 0.89 & 1.58 & 280.2 & 5.33 \\
\hline & \multirow{3}{*}{100} & 0 & 29 & 52 & 68 & 60 & 100 & 104 & 0.95 & 1.72 & 2.16 & 2.10 & 2.82 & 3.14 & 344.5 & 5.99 \\
\hline & & 5 & 38 & 57 & 70 & 69 & 109 & 118 & 0.68 & 1.52 & 1.76 & 2.42 & 3.11 & 3.68 & 353.3 & 6.75 \\
\hline & & 10 & 44 & 60 & 72 & 74 & 118 & 135 & 0.42 & 1.32 & 1.34 & 2.85 & 3.42 & 4.86 & 454.8 & 7.45 \\
\hline \multicolumn{3}{|c|}{$\operatorname{LSD}(0.05)$} & 18.3 & 26.5 & 18.9 & 23 & 10.2 & 9.0 & 0.30 & 0.28 & 0.51 & 0.28 & 0.26 & 0.44 & 88.2 & 2.30 \\
\hline
\end{tabular}

* Treatments= P: kg $\mathrm{P}_{2} \mathrm{O}_{5} / \mathrm{ha}, \mathrm{S}: \mathrm{kg} \mathrm{S} / \mathrm{ha}$ and $\mathrm{Zn:} \mathrm{kg} \mathrm{ZnO/ha.}$

Table (4) also showed that in the presence of S, P uptake by shoots was significantly increased with increasing $\mathrm{Zn}$ rates up to $10 \mathrm{~kg} \mathrm{ZnO} \mathrm{ha-1}^{-1}$, at the booting (ZGS 45) and soft dough (ZGS 85) stages as compared with the control. This may be due to the role of $\mathrm{Zn}$ as a co-factor in the enzymatic reactions and stimulating the plant growth. Similar finding are obtained by Abd El-Maksoud et al. (1993). Similar interpretation was obtained by Gendy et al. (1995) and El-Shahawy (2004). Whereas, when the S fertilizer was not applied, $\mathrm{P}$ uptake by shoots was significantly decreased with increasing $\mathrm{Zn}$ rate to $10 \mathrm{~kg} \mathrm{ZnO} \mathrm{ha}^{-1}$. These results may be due to combination of $P$ with $\mathrm{Zn}$ and its accumulation in roots, while $\mathrm{S}$ application prevented $\mathrm{P}$ accumulation 
Sharaf, A. I.

in roots and increased its translocation to shoots of wheat plant. Similar explanation was mentioned by Zhu et al. (2001) and Abd El-Hafez et al., (2007).

\section{Zinc uptake:}

Table (4) showed that $\mathrm{Zn}$ uptake by roots was significantly increased while it significantly decreased by shoots with the increasing $\mathrm{P}$ and $\mathrm{Zn}$ rates, especially in plots that did not receive $S$, as compared with the control. This trend was clear with the progress of plant growth. Zhu et al., (2001) suggested that the increased $\mathrm{P}$ supply induced a higher physiological $\mathrm{P}$ enhanced $\mathrm{Zn}$ requirement or physiological inactivation of $\mathrm{Zn}$ in plant tissues. On the other hand, opposite trend was obtained with $S$ application. In the presence of $\mathrm{S}, \mathrm{Zn}$ uptake by roots was insignificantly decreased and $\mathrm{Zn}$ uptake by shoots was significantly increased. Khan and Zende (1977) reported that the negativity of $(r)$ values from roots to the leaves and the depression in the mobility of $\mathrm{Zn}$ and $\mathrm{P}$ due to their applications revealed that the $\mathrm{Zn}-\mathrm{P}$ interactions originate in the plant roots, thereby retarding the translocation of each to upper plant parts. As well as, this behavior revealed that the mechanism of this phosphorus-zinc interaction occurs primarily in plant roots, rather than in the soil, and excessive concentrations of phosphorus in the plant roots result in the binding of zinc within root cells. The zinc becomes part of the "fabric" of the root and, therefore, becomes unavailable for transport to shoots and leaves, where it is needed for normal plant growth. Similar explanation was mentioned by Zhu et al., (2001) and Abd El-Hafez et al., (2007).

Table (4) also showed that plots that received $100 \mathrm{~kg} \mathrm{~S} \mathrm{ha}^{-1}$ significantly increased $\mathrm{Zn}$ content in shoots and which indicates $\mathrm{Zn}$ translocation to the shoots. The $\mathrm{Zn}$ uptake was increased from $1.75 \mathrm{mg} / \mathrm{plot}$ at rates of $60 \mathrm{~kg}$ $\mathrm{P}_{2} \mathrm{O}_{5} \mathrm{ha}^{-1}, 10 \mathrm{~kg} \mathrm{ZnO} \mathrm{ha}^{-1}$ plus $0 \mathrm{~kg} \mathrm{~S} \mathrm{ha}^{-1}$ to $4.86 \mathrm{mg} / \mathrm{plot}$ at rates of $120 \mathrm{~kg}$ $\mathrm{P}_{2} \mathrm{O}_{5} \mathrm{ha}^{-1}, 10 \mathrm{~kg} \mathrm{ZnO} \mathrm{ha}^{-1}$ plus $100 \mathrm{~kg} \mathrm{~S}^{-1}$ at the growth stage (ZGS 85). The results also showed that with $S$ application the highest $Z n$ uptake by shoots was obtained. This may be due to the role of $S$ to decrease of soil $\mathrm{pH}$, improve soil structure and increases the availability of certain nutrient elements. Similar interpretation was obtained by Gendy et al., (1995) and ElShahawy (2004). Several researchers have studies had suggested that phytosiderophores also can play a role in $\mathrm{Zn}$ nutrition and thus, quite possibly, Zn efficiency (Hacisalihoglu and Kochian, 2003). With regard to the role of pytosiderophores in Zn nutrition, Zhang et al. (1991) reported that Zn deficient graminaceous species released pytosiderophores and thus increased the mobilization of $\mathrm{Zn}$ and $\mathrm{Fe}$ in soil.

\section{Uptake of $P$ and $Z \mathbf{n}$ by grains:}

Table (4) showed that $P$ and $\mathrm{Zn}$ uptake by grains of wheat plant had increased with increasing of $P$ and $Z n$ rates. The significant increase and highest uptake values, for $\mathrm{P}$ and $\mathrm{Zn}$, were obtained in plots that treated with $\mathrm{S}$. Application of $\mathrm{P}$ and $\mathrm{Zn}$, up to $120 \mathrm{~kg} \mathrm{P}_{2} \mathrm{O}_{5} \mathrm{ha}^{-1}$ and $10 \mathrm{~kg} \mathrm{ZnO} \mathrm{ha}^{-1}$ plus of $100 \mathrm{~kg} \mathrm{~S}$, enhanced $\mathrm{P}$ and $\mathrm{Zn}$ uptake by grains. On the other hand, lower values were obtained in the control (Table, 4). The stimulating effects of phosphorus and zinc on their uptake by grains may be due to their direct effect on enhancing photosynthesis activity in plant. Similar results were 
obtained by El-Ashmoony (1991), El-Shafie (1994) and Abd El-Kader et al. (2007).

Yield and its components:

Tables 5 and 6 showed that application of $P$ and $Z n$ in the absence of $S$ did not significantly increase the yield and its components as comparison with the control. However, the significant increase of the yield parameters and its components were observed by the interaction between $\mathrm{P}$, and $\mathrm{Zn}$ plus $\mathrm{S}$ application (the plots that were treated with $S$ in addition $P$ and $Z n$ ). These results agree with those obtained by Abd El-Fattah et al. (1990), Singh et al. (2005) and Amal et al. (2006). This trend could be due to that addition of S had increased the availability of $P$ and $Z n$ and increased soil supply of $P$ and $\mathrm{Zn}$ to plant. As well as, addition of $\mathrm{S}$ to soil decreased the soil capacity to fix the added $\mathrm{P}$ (Tisdal et al., 1992).

Table (5): The mean values of wheat yield characters at harvest stage for the two growth seasons $\left(1^{\text {st }}\right.$ and $\left.2^{\text {nd }}\right)$ as affected by phosphorus, sulphur and zinc treatments.

\begin{tabular}{|c|c|c|c|c|c|c|c|c|c|c|c|c|c|c|}
\hline \multirow{2}{*}{\multicolumn{3}{|c|}{$\underset{*}{\text { Treatments }}$}} & \multicolumn{12}{|c|}{ yield characters } \\
\hline & & & \multirow[t]{2}{*}{\begin{tabular}{|c|}
$\begin{array}{c}\text { No. of } \\
\text { spikes } \\
\mathrm{m}^{2}\end{array}$ \\
\end{tabular}} & \multirow[t]{2}{*}{ 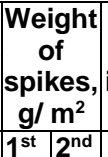 } & $\begin{array}{l}\text { Grain } \\
\text { index, } \mathrm{g}\end{array}$ & $\begin{array}{c}\text { Grain } \\
\text { yield, } \\
\text { ton } \text { ha }^{-1}\end{array}$ & \multicolumn{2}{|c|}{$\begin{array}{c}\text { Straw } \\
\text { yield, ton } \\
\text { ha }^{-1}\end{array}$} & \multicolumn{2}{|c|}{$\begin{array}{c}\text { Biological } \\
\text { yield, ton } \\
\text { ha }^{-1}\end{array}$} & \multicolumn{2}{|c|}{$\begin{array}{l}\text { Harvest } \\
\text { index, \% }\end{array}$} & \multicolumn{2}{|c|}{ Protein, \% } \\
\hline $\mathbf{P}$ & $\mathbf{S}$ & $Z \mathbf{n}$ & & & \begin{tabular}{|l|l|}
$1^{\text {st }}$ & $2^{\text {nd }}$ \\
\end{tabular} & \begin{tabular}{|l|l|}
$1^{\text {st }}$ & $2^{\text {nd }}$ \\
\end{tabular} & $1^{\text {st }}$ & $2^{\text {nd }}$ & $1^{\text {st }}$ & $2^{\text {nd }}$ & $1^{\text {st }}$ & $2^{\text {nd }}$ & $1^{\text {st }}$ & $2^{\text {nd }}$ \\
\hline \multirow{6}{*}{0} & \multirow{3}{*}{0} & & \multirow{2}{*}{\multicolumn{12}{|c|}{ 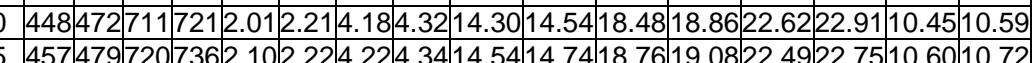 }} \\
\hline & & 5 & & & & & & & & & & & & \\
\hline & & 10 & 465483 & 722740 & 2.132 .21 & \begin{tabular}{|l|l|}
4.31 & 4.41 \\
\end{tabular} & & & & & 22.66 & $2.2 .8+-2$ & & 10.86 \\
\hline & \multirow{3}{*}{100} & 0 & $460 \mid 482$ & 719731 & 2.192 .27 & 4.254 .37 & 14. & 4. & & & 22.3 & 22.6 & 10. & 10.98 \\
\hline & & 5 & $470 \mid 486$ & 730744 & 2.202 .30 & \begin{tabular}{|l|l|}
4.31 & 4.45 \\
\end{tabular} & 14.8 & & 19.1 & $9.5-3$ & $22.4 c$ & 22.8 & $111 .\left({ }^{2}\right.$ & 11.15 \\
\hline & & 10 & \begin{tabular}{|l|l|}
471 & 489 \\
\end{tabular} & 740752 & 2.222 .34 & \begin{tabular}{|l|l|}
4.39 & 4.47 \\
\end{tabular} & & 515.07 & 719.24 & 19.54 & 22.8 & 22.88 & 3111.20 & 11.32 \\
\hline \multirow{6}{*}{60} & \multirow{3}{*}{0} & 0 & $470 \mid 494$ & 749760 & 2.132 .25 & 4.434 .53 & 14.6 & 414.84 & 19.0 & 9.37 & 23.23 & 23.3 & 911. & 11.16 \\
\hline & & 5 & $480 \mid 496$ & $751 / 765$ & 2.182 .26 & \begin{tabular}{|l|l|}
4.45 & 4.5 \\
\end{tabular} & & & & & 23.2 & 4 & & 1.25 \\
\hline & & 10 & & 760770 & \begin{tabular}{|l|l|}
2.20 & 2.28 \\
\end{tabular} & 4.49 & & & & & 23. & 23.5 & & 1.37 \\
\hline & \multirow{3}{*}{100} & 0 & \begin{tabular}{|l|l|}
502 & 518 \\
\end{tabular} & $\mid 769777$ & \begin{tabular}{|l|l|}
2.31 & 2.41 \\
\end{tabular} & 4.564 .66 & & & & & 23.6 & 23.17 & & 11.79 \\
\hline & & 5 & \begin{tabular}{|l|l|}
518 & 524 \\
\end{tabular} & $780 \mid 788$ & 2.332 .45 & $4.60 \mid 4.72$ & & & 20 & 0.27 & 22.9 & 23.2 & 12. & 12.18 \\
\hline & & 10 & & 790800 & 2.422 .52 & \begin{tabular}{|l|l|}
4.684 .76 \\
\end{tabular} & & 5. & & & 23. & 23.40 & 12.5 & 12.58 \\
\hline \multirow{6}{*}{120} & \multirow{4}{*}{\multicolumn{2}{|c|}{0}} & 480500 & $757 \mid 765$ & 2.102 .30 & \begin{tabular}{|l|l|}
4.49 & 4.57 \\
\end{tabular} & 14. & 14.87 & 19. & 9.44 & 23.25 & 23.51 & 11.0 & 11.19 \\
\hline & & & 486502 & 760772 & \begin{tabular}{ll|}
2.21 & 2.35 \\
\end{tabular} & 4.504 .62 & 14.81 & 114.95 & 19.3 & 9.57 & 23.3 & 23.61 & 11.20 & 11.30 \\
\hline & & & 490508 & 765775 & 2.282 .36 & 4.534 .62 & 14. & 015.08 & 319.4 & 19.7 & 23.3 & 23.45 & 11.32 & 11.44 \\
\hline & & & & $770 \mid 782$ & 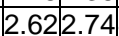 & \begin{tabular}{|l|l|}
4.59 & 4.67 \\
\end{tabular} & & & & & $22 . \varepsilon$ & 23.04 & 412. & 12.21 \\
\hline & \multirow[t]{2}{*}{100} & 5 & 521539 & 776786 & 2.802 .96 & 4.604 .68 & & 15.73 & & & 22.7 & 22.93 & 312.5 & 12.66 \\
\hline & & 10 & & & $3.32 \mid 3.44$ & \begin{tabular}{|l|l|}
4.70 & 4.74 \\
\end{tabular} & & & & & 22. & 22.9 & & 13.35 \\
\hline
\end{tabular}

As clear in Table (6) that the highest values of yield and its components were obtained at highest rates of $P$ and $Z n$ fertilizers combined with $100 \mathrm{~kg} \mathrm{~S}$ ha $^{-1}$. the highest values were 548, 794, 3.38, 4.72, 15.88, 20.60, 22.91 and 13.28 for number of spikes $/ \mathrm{m}^{2}$, weight of spikes $\left(\mathrm{g} / \mathrm{m}^{2}\right)$, grain index $(\mathrm{g})$, grain yield (ton ha-1), straw yield (ton ha-1), biological yield (ton ha-1), harvest index (\%) and protein percentage, respectively. 
Sharaf, A. I.

Table (6): The average values of wheat yield characters at harvest stage for the two growth seasons as affected by phosphorus, sulphur and zinc treatments.

\begin{tabular}{|c|c|c|c|c|c|c|c|c|c|c|}
\hline \multirow{2}{*}{\multicolumn{3}{|c|}{ Treatments * }} & \multicolumn{8}{|c|}{ Characters } \\
\hline & & & \multirow{2}{*}{$\begin{array}{c}\text { No. of } \\
\text { spikes/ } \\
\mathrm{m}^{2}\end{array}$} & \multirow{2}{*}{$\begin{array}{c}\text { Weigh } \\
t \text { of } \\
\text { spikes } \\
\text { g/ m² }\end{array}$} & \multirow{2}{*}{$\begin{array}{c}\text { Grain } \\
\text { index, } \mathbf{g}\end{array}$} & \multirow{2}{*}{$\begin{array}{c}\text { Grains } \\
\text { yield, } \\
\text { ton ha }{ }^{-1}\end{array}$} & \multirow{2}{*}{$\begin{array}{l}\text { Shoots } \\
\text { yield, } \\
\text { ton ha-1 }\end{array}$} & \multirow{2}{*}{$\begin{array}{l}\text { Biologic } \\
\text { al yield, } \\
\text { ton ha-1 }\end{array}$} & \multirow{2}{*}{$\begin{array}{c}\text { Harvest } \\
\text { index, } \\
\%\end{array}$} & \multirow[b]{2}{*}{$\begin{array}{c}\text { Protein, } \\
\%\end{array}$} \\
\hline $\mathbf{P}$ & $\mathbf{S}$ & $\mathrm{Zn}$ & & & & & & & & \\
\hline \multirow{6}{*}{0} & \multirow{3}{*}{0} & \multirow{3}{*}{$\begin{array}{c}0 \\
5 \\
10 \\
\end{array}$} & 460 & 716 & 2.11 & 4.25 & 14.42 & 18.67 & 22.76 & 10.52 \\
\hline & & & 468 & 728 & 2.16 & 4.28 & 14.64 & 18.92 & 22.62 & 10.66 \\
\hline & & & 474 & 731 & 2.17 & 4.36 & 14.71 & 19.07 & 22.86 & 10.82 \\
\hline & \multirow{3}{*}{100} & 0 & 471 & 725 & 2.23 & 4.31 & 14.82 & 19.13 & 22.53 & 10.94 \\
\hline & & 5 & 478 & 737 & 2.25 & 4.38 & 14.85 & 19.23 & 22.78 & 11.10 \\
\hline & & 10 & 480 & 746 & 2.28 & 4.43 & 14.96 & 19.39 & 22.85 & 11.26 \\
\hline \multirow{6}{*}{60} & \multirow{3}{*}{0} & 0 & 482 & 754 & 2.19 & 4.48 & 14.74 & 19.22 & 23.31 & 11.12 \\
\hline & & 5 & 488 & 758 & 2.22 & 4.50 & 14.80 & 19.30 & 23.32 & 11.18 \\
\hline & & 10 & 491 & 765 & 2.24 & 4.54 & 14.85 & 19.39 & 23.41 & 11.32 \\
\hline & \multirow{3}{*}{100} & 0 & 510 & 773 & 2.36 & 4.61 & 15.35 & 19.96 & 23.10 & 11.73 \\
\hline & & 5 & 522 & 784 & 2.39 & 4.66 & 15.48 & 20.14 & 23.14 & 12.12 \\
\hline & & 10 & 535 & 795 & 2.47 & 4.72 & 15.54 & 20.26 & 23.30 & 12.54 \\
\hline \multirow{6}{*}{120} & \multirow{3}{*}{0} & 0 & 490 & 761 & 2.20 & 4.53 & 14.83 & 19.36 & 23.40 & 11.14 \\
\hline & & 5 & 494 & 766 & 2.26 & 4.56 & 14.88 & 19.44 & 23.46 & 11.25 \\
\hline & & 10 & 499 & 770 & 2.32 & 4.58 & 14.99 & 19.57 & 23.40 & 11.38 \\
\hline & \multirow{3}{*}{100} & 0 & 519 & 776 & 2.68 & 4.63 & 15.55 & 20.18 & 22.94 & 12.16 \\
\hline & & 5 & 530 & 781 & 2.88 & 4.64 & 15.68 & 20.32 & 22.83 & 12.62 \\
\hline & & 10 & 548 & 794 & 3.38 & 4.72 & 15.88 & 20.60 & 22.91 & 13.28 \\
\hline \multicolumn{3}{|c|}{$\operatorname{LSD}(0.05)$} & 45.60 & 56.82 & 0.28 & 0.42 & 0.46 & 0.98 & 0.72 & 0.98 \\
\hline
\end{tabular}

${ }^{*}$ Treatments= P: $\mathbf{k g ~ P}_{2} \mathrm{O}_{5} / \mathrm{ha}, \mathrm{S}: \mathrm{kg} \mathrm{S} / \mathrm{ha}$ and $\mathrm{Zn:} \mathrm{kg} \mathrm{ZnO/ha}$

\section{Relative variation of yield:}

Table 7 showed that the values of the relative variation of the dry weight with respect to the control $(P=0, S=0$ and $Z n=0)$ showed that negative values $(-2.7$ an $-0.4 \%$ for the treatments: $P=0, S=0$ and $Z n=5$, and $P=0, S=0$ and $\mathrm{Zn}=10$, respectively). This indicates that was most of applied $\mathrm{Zn}$ to the soil has been changed to unavailable form and did not improve plant growth

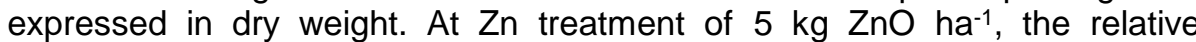
decrease of dry weight was $7.2 \%$ and with $10 \mathrm{~kg} \mathrm{ZnO} \mathrm{ha}^{-1}$ the relative decrease was 0.4 , which indicates the tow rates no positive effects on plant yield and in order to increase plant yield, higher $\mathrm{Zn}$ rates should be application.

Application of $100 \mathrm{~kg} \mathrm{~S} \mathrm{ha-1}^{-1}$ had increased the plant dry weight as indicated by the values of the relative increase $(1.9,27.4$, and $69.7 \%$ for $0 \mathrm{~kg}$ $\left.\mathrm{ZnO} \mathrm{ha}^{-1}\right)$. This points out to the stimulating action of $\mathrm{S}$ on plant growth. With increasing $\mathrm{Zn}$ application in combination with $100 \mathrm{~kg} \mathrm{~S}^{-1}$, the relative increases of dry weight were 1.9, 3.1 and $3.8 \%$ for 0,5 , and $10 \mathrm{~kg} \mathrm{ZnO} \mathrm{ha}^{-1}$ respectively (Table, 7 ).

Application of $60 \mathrm{~kg} \mathrm{P}_{2} \mathrm{O}_{5}$ ha $^{-1}$ with $\mathrm{Zn}$ treatments increased the relative dry weight to values of $18.8,23.6$ and $28.2 \%$ with 0,5 , and $10 \mathrm{~kg} \mathrm{ZnO} \mathrm{ha-1}^{-1}$, respectively. These values were $31.0,37.9$ and $40.2 \%$ for 0,5 , and $10 \mathrm{~kg}$ 
$\mathrm{ZnO} \mathrm{ha}^{-1}$, respectively with $120 \mathrm{~kg} \mathrm{P}_{2} \mathrm{O}_{5} \mathrm{ha}^{-1}$. These results indicate that application of $\mathrm{P}$ in combination with $\mathrm{Zn}$ to calcareous soil increased the growth of wheat plant expressed as dry weight (Table, 7 ).

Table (7): The Relative variation of the control with $P, S$ and $Z n$ treatments for wheat plant grown in calcareous soil.

\begin{tabular}{|c|c|c|c|}
\hline \multirow{2}{*}{\multicolumn{3}{|c|}{ Treatments * }} & \multirow{3}{*}{$\begin{array}{c}\text { Relative variation of the control } \\
\%\end{array}$} \\
\hline & & & \\
\hline $\mathbf{P}$ & $\mathbf{S}$ & Zn & \\
\hline \multirow{6}{*}{0} & \multirow{3}{*}{0} & \multirow{3}{*}{$\begin{array}{c}0 \\
5 \\
10\end{array}$} & -- \\
\hline & & & -2.7 \\
\hline & & & -0.4 \\
\hline & \multirow{3}{*}{100} & \multirow{3}{*}{$\begin{array}{c}0 \\
5 \\
10\end{array}$} & 1.9 \\
\hline & & & 3.1 \\
\hline & & & 3.8 \\
\hline \multirow{6}{*}{60} & \multirow{3}{*}{0} & \multirow{3}{*}{$\begin{array}{c}0 \\
5 \\
10\end{array}$} & 18.8 \\
\hline & & & 23.0 \\
\hline & & & 28.2 \\
\hline & \multirow{3}{*}{100} & \multirow{3}{*}{$\begin{array}{c}0 \\
5 \\
10 \\
\end{array}$} & 27.4 \\
\hline & & & 44.4 \\
\hline & & & 61.7 \\
\hline \multirow{6}{*}{120} & \multirow{3}{*}{0} & \multirow{3}{*}{$\begin{array}{c}0 \\
5 \\
10\end{array}$} & 31.0 \\
\hline & & & 37.9 \\
\hline & & & 40.2 \\
\hline & \multirow{3}{*}{100} & \multirow{3}{*}{$\begin{array}{c}0 \\
5 \\
10\end{array}$} & 69.7 \\
\hline & & & 88.5 \\
\hline & & & 141.0 \\
\hline
\end{tabular}

* Treatments= P: $\mathbf{k g ~ P}_{2} \mathrm{O}_{5} / \mathrm{ha}, \mathrm{S}: \mathrm{kg} \mathrm{S} / \mathrm{ha}$ and $\mathrm{Zn:} \mathrm{kg} \mathrm{ZnO/ha}$.

Application of $\mathrm{S}$ in combination with $60 \mathrm{~kg} \mathrm{P}_{2} \mathrm{O}_{5} \mathrm{ha}^{-1}$ increased the relative yield by values of $27,44.4$ and $61.7 \%$ with 0,5 and $10 \mathrm{~kg} \mathrm{ZnO} \mathrm{ha-1}^{-1}$, respectively. These relative increases were $69.7,88.5$ and $141.0 \%$ with 120

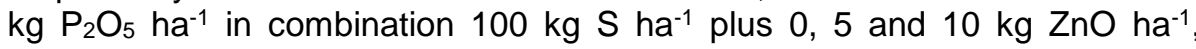
respectively.

It is interesting to notice that application of $120 \mathrm{~kg} \mathrm{P}_{2} \mathrm{O}_{5}$ ha $^{-1}$ produce lower relative dry weight (31.0, 37.9 and $40.2 \%)$ without $\mathrm{S}$ application and with 0,5 , and $10 \mathrm{~kg} \mathrm{ZnO} \mathrm{ha-1}^{-1}$, respectively, than with $\mathrm{S}$ application (69.7, 88.5 and $141.0 \%$, respectively). The same trend was found with application of $60 \mathrm{~kg} \mathrm{P}_{2} \mathrm{O}_{5} \mathrm{ha}^{-1}$ without S application (18.8, 23.6 and $28.2 \%$, respectively) and with S application (27, 44.4 and $61.7 \%$ with 0,5 and $10 \mathrm{~kg} \mathrm{ZnO} \mathrm{ha}^{-1}$, respectively). These results reveal the role of $S$ application for improving wheat plant growth and that $\mathrm{S}$ had stimulated the role of both $\mathrm{P}$ and $\mathrm{Zn}$ for plant growth (Table, 7).

It is clear from these results that $120 \mathrm{~kg} \mathrm{P}_{2} \mathrm{O}_{5} \mathrm{ha}^{-1}, 100 \mathrm{~kg} \mathrm{~S}^{-1}$ and 10 $\mathrm{kg} \mathrm{ZnO} \mathrm{ha-1} \mathrm{had} \mathrm{produced} \mathrm{the} \mathrm{highest} \mathrm{relative} \mathrm{dry} \mathrm{weight} \mathrm{with} \mathrm{the} \mathrm{respect} \mathrm{to}$ control.

\section{Conclusion:}

The obtained results showed that application of $\mathrm{Zn}$-fertilizer in combination with $\mathrm{P}$ and $\mathrm{S}$ application to the $\mathrm{Zn}$-deficient calcareous soil had improved the growth characters of wheat plant grown on this soil especially.

6275 
High $\mathrm{P}$ fertilizer rate alone had increased markedly but not significantly grains yield while applying $100 \mathrm{~kg} \mathrm{ha}^{-1}$ in combination with $120 \mathrm{~kg} \mathrm{P}_{2} \mathrm{O}_{5} \mathrm{ha}^{-1}$ had increased significant grains yield and all wheat yield components. Also, application of $\mathrm{Zn}$ in combination with $\mathrm{S}$ significantly increased all growth components and grain yield. The results showed that applications of $120 \mathrm{~kg}$ $\mathrm{P}_{2} \mathrm{O}_{5} \mathrm{ha}^{-1}$ in combination with $10 \mathrm{~kg} \mathrm{ZnO} \mathrm{ha-1}^{-1}$ and $100 \mathrm{~kg} \mathrm{~S}^{-1}$ had produced high significant yields of wheat plant grown in infertile calcareous soil.

\section{REFERENCES}

Abd El-Fattah, A.; M.A. Hilal; K.M. El-Habbasha, and M.D. Bakry (1990). Amendment of alkaline clay soil by elemental sulphur and its effect on the response of garlic to phosphorus and nitrogen. Middle East Sulphur Symposium, Cairo, pp. 295-313.

Abd El-Hafez, S.A.; A.M. El-Ghamry and A.M. El-Emshaty (2007). Integrated fertilization for wheat crop under sandy soil condation. J. Agric. Sci. Mansoura Univ., 32(5): 4017-4028.

Abd El-Kader, M.G.; H.S. Siam and A.A. Azoz (2007). Effect of phosphorus rates and methods of zinc application on maize yield and its components. J. Agric. Sci. Mansoura Univ., 32(5): 3959-3969.

Abd El-Maksoud, M. M. R.; S. S. Megalah and A. S. Abd El-Nour (1993). Response of bean plants to different sources of $\mathrm{Zn}$. Menofiya J. Agric. Res., 18(3) 1827-1836.

Aksoy,T.(1974). Dörtyol D.Ü.Ç. Turunçgiller işletmesinde portakallarda görülen çinko noksanlığının fosfor ile ilişkisi üzerine bir araştırma. A.Ü. Z. F. Yayınları, 627 Ankara.

Amal, G.A., M.S. Hassanein and M.M. El-Gazzar (2006). Growth and Yield Response of Two Wheat Cultivars to Complete Foliar Fertilizer Compound "Dogoplus". J. App. Sci. Res. 2(1): 20-26.

Bergman, W. (1992). Nutritional Disorders of Plants. Development, Visual and Analytical Diagnosis. Gustav Fisher Verlag Jena. Stutgart. New York.

Chapman, H. D. and Pratt, P. F. (1961). Methods of analysis for soil, plants and water. Uni. Of California. Div. Agric. Sci., p. 309.

El-Ashmoony, M.S.F. (1991). Effect of split application of phosphorus fertilizer level on yield and grain quality of wheat. Minia J. Agric. And Dev. 13(3): 1197-1208.

El-Shafie, F.S. (1994). Effect of phosphorus and zinc application on growth and nutrients distribution of broad bean plants. Zagazig J. Agric. Res. 20(6)20-29.

El-Moatasem, M. O.; Abo El-Khair, R. A.; El-Wakeel, A. A. and Fayed, R. M. (1993). Effect of nitrogen and zinc fertilization on their uptake and rice dry matter yield. Menofiya J. Agric. Res., 18: 515-524.

El-Shahawy, M. I. (2004). Response of sugarbeet and subsequent crops to sulphur, sulphur oxidation bacteria and organic wastes application under salt affected soils. J. Agric. Sci. Mansoura Univ., 29 (6):36613677.

FAO (1970). Physical and Chemical Methods of Soil and Water Analysis. Food and Agriculture Organization of the United Nations. Rome.

FAO (2002). World agriculture towards 2015/2030.Summary report. Food And Agriculture Organization of The United Nations. Rome. 
Gee, G.W., and J.W. Bauder (1986). Particle-size analysis. Pages 383-412. In: Methods of Soil Analysis: Physical and Mineralogy Methods, Part 1. Second ed., A. Klute, ed. ASA and SSSA, Madison, WI.

Gendy, E.M.; S.A.A. El-Raies and Abed M.A. El-Reheem (1995). Effect of number of irrigations and sulphur application on broad bean growth and yield. Egypt J. Soil Sci., 35(3): 379-393.

Gomez, K. A., and A. A. Gomez (1984). Statistical Procedures for Agricultural Research, with Emphasis on Race. International Institute, Los Banos, Philippines.

Graham RD and Z. Rengel (1993). Genotypic variation in Zn uptake and utilization by plants. In: Robson D, ed. Zinc in soils and plants. Dordrecht, The Netherlands: Kluwer Academic Publishers, 107-114.

Hacisalihoglu, G. and L.V. Kochian (2003). How do some plants tolerate low levels of soil zinc? Mechanisms of zinc efficiency in crop plants. Research review. New Phytologist, 159: 341-350.

Hawkesford, M.J. (2000). Plant responses to sulphur deficiency and the genetic manipulation of sulfate transporters to improve S-utilization efficiency. J. Exp. Botany, Vol. 51 No. 342: 131-138.

Hesse, P. R. (1972). A Textbook of Soil Chemical Analysis. Chem. Pub. Co. Inc., New York, NY.

IFAD, (1991). Egypt West Nubaria Intensification Project. IFAD/WB/GOE.

IFPRI (2002). Reaching sustainable food security for all by 2020: Getting the priorities and responsibilities right. International Food Policy Research Institute. Washington, DC.

IFPRI (International Food Policy Research Institute). (2004). Africa's Food and Nutrition Security Situation "A 2020 Vision for Food, Agriculture, and the Environment". Washington, DC.

Kanwar, J.S. and L.J. Youngdahl (1985). Micronutrient needs of tropical food crops. Fertil. Res. 7, 43-68

Khan A.A. and G.K. Zende (1997). The site for Zn-P interactions in plants. Plant and Soil. Vol. 46, No. 1: 259 - 262

Kherallah, M., H. Löfgren, P. Gruhn and M.M. Reeder (2000). Wheat Policy Reform in Egypt. Research Report 115, International Food Policy Research Institute, Washington, D.C.: IFPRI.

Lindsay, W.L., and Norvell, W.A. 1978. Development of a DTPA soil test for zinc, iron, manganese and copper. Soil Sci. Soc. of Am. J.42:421.428.

Sci. Soc. Amer., Madison, WI.

Mengel, K., and E. A. Kirkby (2001). Principles of Plant Nutrition (5th ed.) (p. 594). Dordrecht: Kluwer Academic Publishers.

Miller, T. D. (1992). Growth Stages of Wheat: Identification and Understanding Improve Crop Management. Better Crops. 76 (3): 12 17.

Page, A. L.; R. H. Miller and D. R. Keeney (Ed.) (1982). Methods of Soil Analysis. Part 2. No. 9 (Part 2) in the series Agronomy Am. Soc. of Agro. Madison, Wis. USDA.

Parker, D.R.; J.J. Aguilera; D.N. Thomason (1992). Zinc-Phosphorus interactions in Two Cultivars of Tomato (Lycopersicon Esculentum L.) Grown in Chelator-Buffered Nutrient Solutions. Plant and Soil 143: 163177.

Rammah, A. (1989). Forage production polices and wheat utilization. In: Wheat production strategy and its future in Egypt 1989. The Academy of Scientific Research and Technology, the International Egyptian Center for Agriculture (in Arabic language), pp. 361-370.

Richards, L. A. (1954). Diagnosis and Improvement of Saline and Alkali Soils. U.S.D.A. Handbook No. 60 Washington, D. C., U.S.A. 
Sharaf, A. I.

Sillanpaa, M (1982). Micronutrients and the nutrient status of soils. A global study. FAO Soil Bulletin No. 48, FAO. Rome, Italy.

Sillanpaa M. (1990). Micronutrient assessment at the country level; an international study. Rome, Italy: Food and Agriculture Organization of the United Nations.

Singh B.; S. A. Natesan; B. K. Singh and K. Usha (2005). Improving zinc efficiency of cereals under zinc deficiency. Current Science, Vol. 88, No. 1: $36-44$.

Tabatabai, M.A (1982). Sulfur. P. 501-538. In: Methods of Soil Analysis: Chemical and Microbiological Properties, Part 2., $2^{\text {nd }}$ ed., A.L. Page, ed. ASA and SSSA, Madison, WI.

Tisdal, S.L.; W.L. Nelson and J.D. Beaton (1992). Soil fertility and fertilizers. Macmillan Pub. Co., $4^{\text {th }}$ ed., New York, Chapter 6, pp. 189-248.

Zadoks, I.C.; T.T. Chang and C.F. Konzak (1974). Weed research 14, 415421.

Zhang F, F.V. Romheld; and H. Marschner (1991). Release of Zn mobilizing root exudates in different plant species as affected by $\mathrm{Zn}$ nutritional status. Journal of Plant Nutrition 14: 675-686.

Zhu Y.G; S. E. Smith and F. A. Smith (2001). Zinc (Zn)-phosphorus (P) Interactions in Two Cultivars of Spring Wheat (Triticum aestivum L.) Differing in P Uptake Efficiency. Annals of Botany 88: 941 \pm 945 .

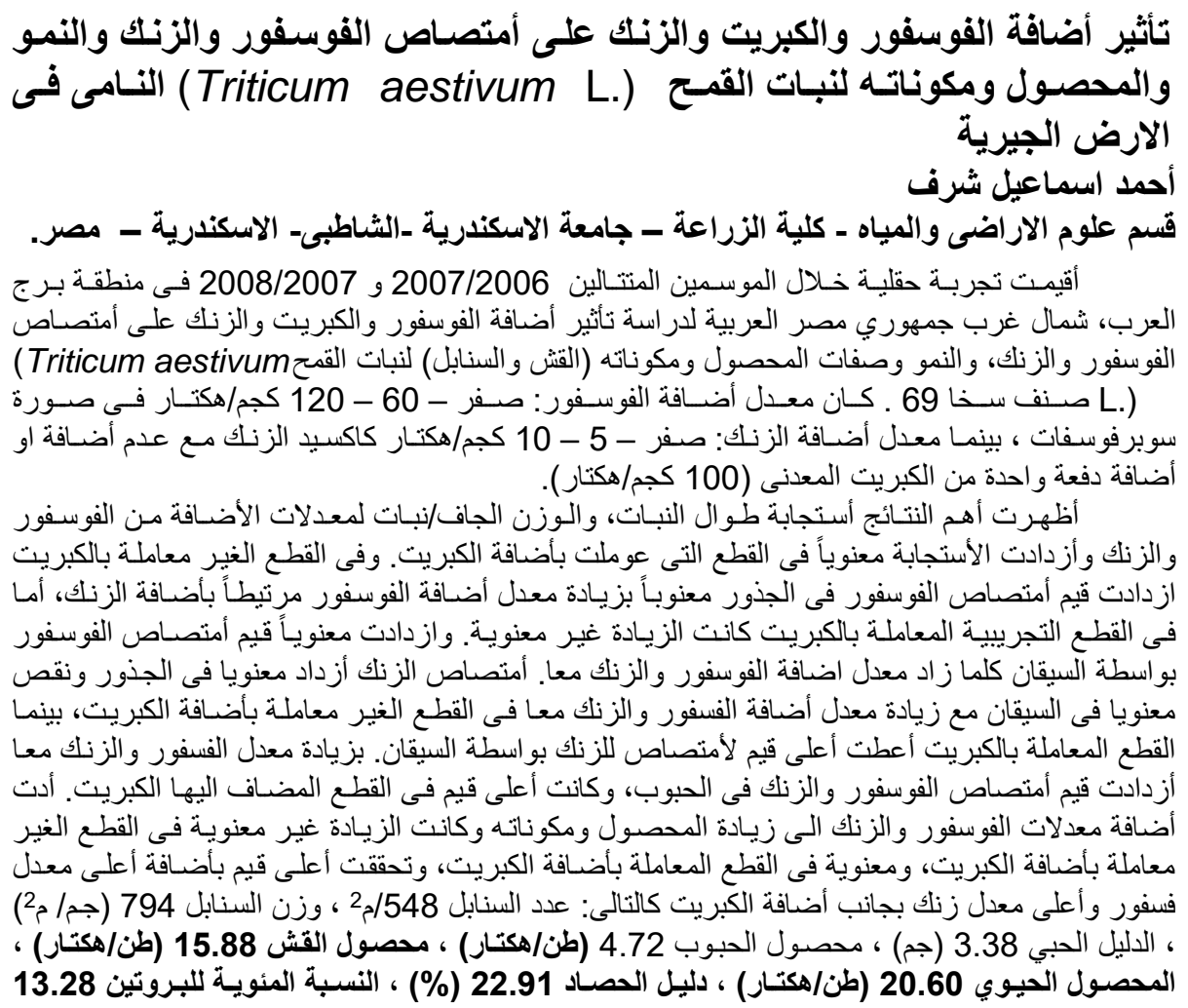

